\title{
The Effect of Co-Creation on the Performance of Indonesian Wholesale Carrier Service Companies
}

\author{
"Edwin Aristiawan', Sucherly², Sulaeman Rahman Nidar', Umi Kaltum \\ ${ }^{l}$ Doctorate of Management Science, Faculty of Business and Economics, Padjadjaran University. \\ ${ }^{2}$ Doctorate of Management Science, Faculty of Business and Economics, Padjadjaran University. \\ ${ }^{3}$ Doctorate of Management Science, Faculty of Business and Economics, Padjadjaran University. \\ ${ }^{4}$ Doctorate of Management Science, Faculty of Business and Economics, Padjadjaran University. \\ "Corresponding author. E-mail: edwin.aristiawan88@gmail.com
}

\begin{abstract}
This study aims to determine the effect of the co-creation approach on businesses in the Wholesale Carrier Service market, focusing on Network and Infrastructure in Indonesia. This research uses a quantitative causality research design with the sample is 46 Wholesale Carrier Service industry with the scope of Network and Infrastructure in Indonesia. The hypothesis was tested using Partial Least Squares (PLS) to evaluate the association between two latent variables. The findings indicated that the co-creation strategy had a sizable impact on the company's performance. In general, this document intends to contribute to the strategic planning of the Wholesale Carrier Service organization and serve as a guide for resource allocation to maintain sustainable growth.
\end{abstract}

Keywords: Co-creation Strategy, Company Performance, Wholesale Carrier Service Company with a Network and Infrastructure Scope.

\section{INTRODUCTION}

Current technological developments encourage most telecommunication companies to direct their business lines by expanding into the provision of content services, applications, digital services, and digital solutions. Due to technological developments, market diversification that occurs in the telecommunications industry is a business opportunity that telecommunications companies can maximize as solution providers for each of these segments. The marketing strategy also should be adjusted based on the characteristics of the segment of the business and targeted customers in order to more effectively and efficiently. The characteristics differences of each of these customer segments certainly also have different challenges. In the segment Consumer, operators are faced with the conditions market that is very fragile, head to head on the competition due to the customer sensitivity to the price paid for the product, customer experience, feature, and after-sales service provided by the operator. On the segment Enterprise, the service providers compete to provide highly customized solutions required by segment customers enterprise (the company), SMEs, and government agencies. Segment wholesale has unique characteristics, where they play a role as an enabler for the operating business segments consumer and enterprise, both for internal Telkom or other telecommunications operators, such as the provision of access backbone link, sea cable, satellite, and BTS tower (Base Transceiver Station).

In a digital ecosystem, the main aspects that become a necessity are components Device, Network, Infrastructure, and Applications. Aspect Network and Infrastructure as a fundamental component that must be available in holding ICT services are services that providers urgently need to connect devices or devices with customers in carrying out their products and services operations. Since the cost of investment required to build the Network and Infrastructure itself is relatively expensive, this is an opportunity for the segment wholesale operators to rent the Network and the Infrastructure owned. Some of the primary products and services in the business segments wholesale network and infrastructure offered by the telecommunications operator company in Indonesia, such as Network Service (IPLC \& LC), Satellite, IP Transit, Metro-E, and Tower. Submarine Cable, Energy \& Construction Solution. Based on the data up to September 2019 (LAPI ITB, 2019), the mobile services provider companies are actively building new BTS $4 \mathrm{G}$ in some areas of Indonesia. 
The connectivity growth of both backhaul and backbone rose significantly in Java and Sumatra, Sulawesi, Bali, Nusa Tenggara, and Kalimantan. The increasing distribution of BTS in areas outside Java indicates the availability of the backhaul and backbone connectivity outside Java is getting better, and it also indicates the increased competition in the segment wholesale network and infrastructure. The main focus of cellular service providers in 2019 is improving network quality in Java through fiberization and expanding coverage outside Java, such as Sumatra, Sulawesi, and Kalimantan. The network quality and coverage will be the key in improving services to retain the existing customers and get new customers to improve the company's revenue.

Table 1. The Wholesale Carrier Service Company's Revenue with the scope of Network and Infrastructure in Indonesia the Period 2016-2020 (in billion)

\begin{tabular}{|c|c|c|c|c|c|c|}
\hline Row Labels & 2016 & 2017 & 2018 & 2019 & 2020 & Grand Total \\
\hline TELKOM & 8.053 & 9.300 & 6.552 & 6.364 & 3.309 & 33.580 \\
\hline INDOSAT & 1.603 & 1.751 & 1.115 & 1.134 & & 5.605 \\
\hline MORATEL & 1.166 & 1.517 & 977 & 1.057 & & 4.718 \\
\hline$X L$ & 660 & 740 & 679 & 742 & & 2.822 \\
\hline ICON PLUS & 428 & 448 & 474 & 523 & & 1.875 \\
\hline PGASCOM & 166 & 188 & 191 & 275 & & 821 \\
\hline FIRST MEDIA & 222 & 264 & 91 & 48 & & 627 \\
\hline Grand Total & 12.301 & 14.210 & 10.081 & 10.147 & 3.309 & 50.051 \\
\hline
\end{tabular}

The table above shows the total increase in the wholesale carrier service company's revenue with scope network and infrastructure in Indonesia in the year 2017 when compared with 2016. However, it decreased again in 2018. The increase in 2019 was not significant. The conditions above indicate the suboptimal business performance in the industry of wholesale network. While the pandemic puts pressure on wholesale provider profitability, this situation is not optimum in the wholesale business network, given the demand potential from the rise in data traffic. At the same time, the telecommunications sector's performance during the pandemic is better than the other infrastructure subsectors. Different from many other industries, the telecommunications sector is generally exempt from restrictions related to Covid19 , such as the orders to stay home and quarantine requirements, because it is considered an essential service. Some telecommunications companies are experiencing an increase in data traffic and broadband services, as more people work from home and rely on video conferences to hold meetings. Meanwhile, wholesale carrier services with the scope of network and infrastructure have the potential for the market to continue to grow due to mobile operators' high number of subscribers. Also, the growing number of internet users will increase the demand for networks and infrastructure to support the increased use of such data.

In the past, companies are synonymous with competition. Companies must open the door as wide as possible to collaborate. Companies must innovate in co-creation. It means the company we used to think of as competitors should be seen as colleagues or partners. Through co-creation, ICT companies that have been around for a long time can be creative with their consumers, starting from partners in the form of business to business to consumer (B2B2C) cooperation, or be creative with individual consumers in the form of business to consumer (B2C). Because, in a sense, consumers are the ones who understand best what they need in a product or service. By involving them, we could produce the best product or service, which is indeed desired by the market.

\section{LITERATURE REVIEW}

\subsection{Co-Creation Strategy and Company's Performance}

Co-creation is thought to be a strategy for increasing value for both customers and the business [1]. The prefix "co-" in Co-creation refers to the players involved in value creation and includes the consumer, the firm, the community brand, and other stakeholders [2]. The discovered that co-creation had a positive effect on the business success [3]. Additionally, co-creation activities have direct and indirect consequences on businesses and customers [4]. Meanwhile, discovered that organizational performance is significantly influenced by differentiation strategy and service innovation. 
Additionally, differentiation is an important component of a competitive strategy. Additionally, discovered that organizational performance is significantly influenced by differentiation strategy and service innovation [5]. The discovered that competitive strategy enhances firm performance favorably and considerably through performance assessment [6].

The co-creation between the business and its customers is one of the new ways used by the company for the development of products and services. Cocreation is when a company works with its customers to manufacture or develop a new product or service [7]. Co-creation occurs when a business collaborates closely with individuals or other businesses to develop new goods, develop new ideas in logistics, or innovate [7].

Co-creation strategy value describes how the network organization gains a competitive advantage by involving customers and business partners in the process of co-creation value. Give insight into consumer and business co-creation-related effects on the corporate success[ 8]. Orientations have been examined in the context of service co-creation, demonstrating that efforts toward service co-creation affect business performance. The link between the stages of co-creation by companies and more excellent company development and profitability have been extensively examined [9].

\section{METHODOLOGY}

This paper used a quantitative research method with descriptive and causality design in which the researcher collects and analyzes data, integrates findings, and concludes. The research uses a wholesale carrier service firm as the unit of analysis, with network and infrastructure as the observation unit. The researchers focused on co-creation around Businessto-Business (B2B) themes. Quantitative data collection methods were carried out online and offline. Questionnaires were distributed to the Directors and Senior Leaders of Wholesaler Telecommunication Companies in Indonesia. This study used a one-shot temporal frame and cross-sectional data.

To examine the hypothesis in this study, the researcher uses Partial Least Square (PLS), an analytical model developed from Structural Equation Modeling (SEM). This structural equation model reflects the link between latent variables and measurement components that demonstrate the relationship between latent variables and their indicators. The samples are 45 randomly taken surveys from Wholesaler Telecommunication Companies in Indonesia. The research population is a wholesale carrier service company with the scope of network and infrastructure in Indonesia.

\section{RESULT}

We developed our study instrument using the processes outlined by Hair, Anderson, Tatham, and Black to ensure the questionnaire's validity and reliability [10]. The loading factor value determines the reflecting model's convergent validity; each observed variable is valid if the loading factor value is more significant than 0.5 . The loading factor values for the observed variables are shown in Table 1 , and the estimation result is shown in Figure 1, which was processed using the SmartPLS3.0 tool. 


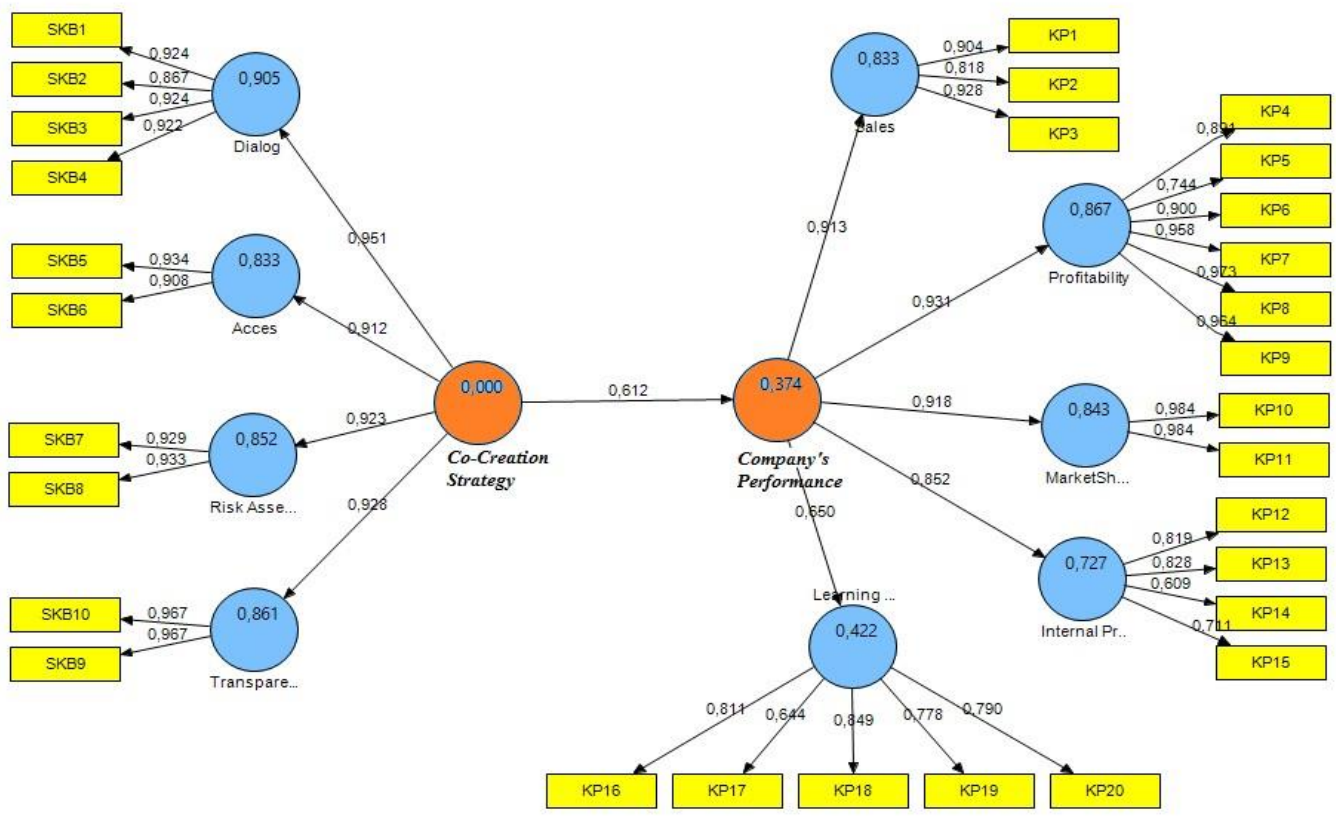

Figure 1. The Path Coefficient

Convergent validity will be determined using the average variance extracted (AVE) index. It was utilized to determine the research findings' Convergent validity. The minimum allowable standard deviation retrieved is 0.5 [11]. As each latent variable has a value of more than 0.7 , the composite reliability score indicates that all models are reliable. Each item must have a factor loading of at least 0.50 . According to Figure 1 and Table 1, if all loading factor values for observed variables are more significant than 0.5 (valid), the significance threshold is 0.95 and t-values greater than 1.96 are accepted, then all variables are suitable for inclusion in the model.

Table 2. Construct Reliability and Convergent Validity

\begin{tabular}{|c|c|c|c|c|c|}
\hline Variable & Dimension-Indicator & $\begin{array}{l}\text { Loading } \\
\text { Factor }(x)\end{array}$ & t value & $\begin{array}{c}\text { Average } \\
\text { Variance } \\
\text { Extracted } \\
\text { (AVE) }\end{array}$ & $\begin{array}{l}\text { Composite } \\
\text { Reliability } \\
\text { (CR) }\end{array}$ \\
\hline \multirow{10}{*}{$\begin{array}{l}\text { Company } \\
\text { Performance }\end{array}$} & Company Performance -> Sales & 0.913 & 68.677 & 0.782 & 0.915 \\
\hline & KP1 <- Sales & 0.904 & 47.456 & & \\
\hline & KP2 <- Sales & 0.818 & 21.175 & & \\
\hline & KP3 <- Sales & 0.928 & 86.226 & & \\
\hline & $\begin{array}{l}\text { Company Performance -> } \\
\text { Profitability }\end{array}$ & 0.931 & 81.241 & 0.825 & 0.966 \\
\hline & KP4 <- Profitability & 0.891 & 41.540 & & \\
\hline & KP5 <- Profitability & 0.744 & 11.280 & & \\
\hline & KP6 <- Profitability & 0.900 & 31.219 & & \\
\hline & KP7 <- Profitability & 0.958 & 121.741 & & \\
\hline & KP8 <- Profitability & 0.973 & 194.502 & & \\
\hline
\end{tabular}




\begin{tabular}{|c|c|c|c|c|c|}
\hline & KP9 <- Profitability & 0.964 & 143.453 & & \\
\hline & $\begin{array}{l}\text { Company Performance -> Market } \\
\text { Share }\end{array}$ & 0.918 & 60.780 & 0.968 & 0.984 \\
\hline & KP10 <- Market Share & 0.984 & 230.883 & & \\
\hline & KP11 <- Market Share & 0.984 & 243.935 & & \\
\hline & $\begin{array}{l}\text { Company Performance -> Internal } \\
\text { Process }\end{array}$ & 0.852 & 34.357 & 0.558 & 0.833 \\
\hline & KP12 <- Internal Process & 0.819 & 24.161 & & \\
\hline & KP13 <- Internal Process & 0.828 & 19.387 & & \\
\hline & KP14 <- Internal Process & 0.609 & 7.212 & & \\
\hline & KP15 <- Internal Process & 0.711 & 10.210 & & \\
\hline & $\begin{array}{l}\text { Company Performance -> Learning } \\
\text { \& Growth }\end{array}$ & 0.650 & 9.459 & 0.604 & 0.883 \\
\hline & KP16 <- Learning \& Growth & 0.811 & 20.135 & & \\
\hline & KP17 <- Learning \& Growth & 0.644 & 6.488 & & \\
\hline & KP18 <- Learning \& Growth & 0.849 & 19.529 & & \\
\hline & KP19 <- Learning \& Growth & 0.778 & 7.407 & & \\
\hline & KP20 <- Learning \& Growth & 0.790 & 25.454 & & \\
\hline Co-Creation & Co-Creation Strategy -> Dialogue & 0.951 & 90.500 & 0.827 & 0.950 \\
\hline & SKB1 <- Dialogue & 0.924 & 35.786 & & \\
\hline & SKB2 <- Dialogue & 0.867 & 23.520 & & \\
\hline & SKB3 <- Dialogue & 0.924 & 49.585 & & \\
\hline & SKB4 <- Dialogue & 0.922 & 47.663 & & \\
\hline & Co-Creation Strategy -> Access & 0.912 & 49.740 & 0.848 & 0.918 \\
\hline Variable & Dimension-Indicator & $\begin{array}{l}\text { Loading } \\
\text { Factor (ג) }\end{array}$ & t value & $\begin{array}{l}\text { Average } \\
\text { Variance } \\
\text { Extracted } \\
\text { (AVE) }\end{array}$ & $\begin{array}{l}\text { Composite } \\
\text { Reliability } \\
\quad \text { (CR) }\end{array}$ \\
\hline & SKB5 <- Access & 0.934 & 87.658 & & \\
\hline & SKB6 <- Access & 0.908 & 31.962 & & \\
\hline & $\begin{array}{l}\text { Co-Creation Strategy -> Risk } \\
\text { Assessment }\end{array}$ & 0.923 & 56.291 & 0.867 & 0.929 \\
\hline & SKB7 <- Risk Assessment & 0.929 & 50.619 & & \\
\hline & SKB8 <- Risk Assessment & 0.933 & 60.559 & & \\
\hline & $\begin{array}{l}\text { Co-Creation Strategy -> } \\
\text { Transparency }\end{array}$ & 0.928 & 68.976 & & \\
\hline & SKB9 <- Transparency & 0.967 & 120.273 & 0.935 & 0.966 \\
\hline & SKB10 <- Transparency & 0.967 & 123.231 & & \\
\hline
\end{tabular}


The R-square predictive relevance (Q-square value) and the Goodness of Fit assess the inner model (GoF). According to Chin, R-Square values of 0.67 indicate a strong relationship, 0.33 indicate a moderate relationship, and 0.19 indicate a poor relationship. The
GOF is used to validate the relationship between the measurement and structural models, with values ranging from 0 to 0.25 (simple), 0.25 to 0.36 (moderate), and > 0.36 (complex) (large) [12].

Table 3. Evaluation of Inner Model (Structural Model)

\begin{tabular}{lccc}
\hline Variable $\quad$ R- & Communality & Goodness of Fit Square & (GoF) Index \\
\hline Co-Creation Strategy & & 0.749 & 0.49 \\
\hline Company Performance & 0.374 & 0.537 & \\
\hline
\end{tabular}

The table below summarizes the procedure for determining the co-efficiency of endogenous Constructs. R-square is moderate-strong, while GOF is significant. Given that the model has an acceptable fitness level of 0.36 and a value of 0.49 , we infer that the model has an acceptable fitness level.

Table 4. Hypothesis Testing

\begin{tabular}{llllllll}
\hline No & Structural Model & $\begin{array}{c}\text { Path } \\
\text { Coeff. }\end{array}$ & $\begin{array}{c}\text { Std. } \\
\text { Error }\end{array}$ & t value & Prob. & $\mathbf{R}^{2}$ & Conclusion \\
\hline 1 & $\begin{array}{l}\text { Co-Creation Strategy }->\text { Company } \\
\text { Performance }\end{array}$ & 0.612 & 0.066 & $9,288^{*}$ & 0.000 & 0.374 & Significant \\
\hline
\end{tabular}

Based on the results obtained (Table 3), Cocreation strategies have a good and significant impact on the performance of businesses. $(\gamma$ Eleven $=0.612$, prob. < 0.05). The impact is substantial, with a significance level of $95 \%$ and a value larger than 1,96, the impact is substantial. $\mathrm{R}^{2}$ is $37.4 \%$.

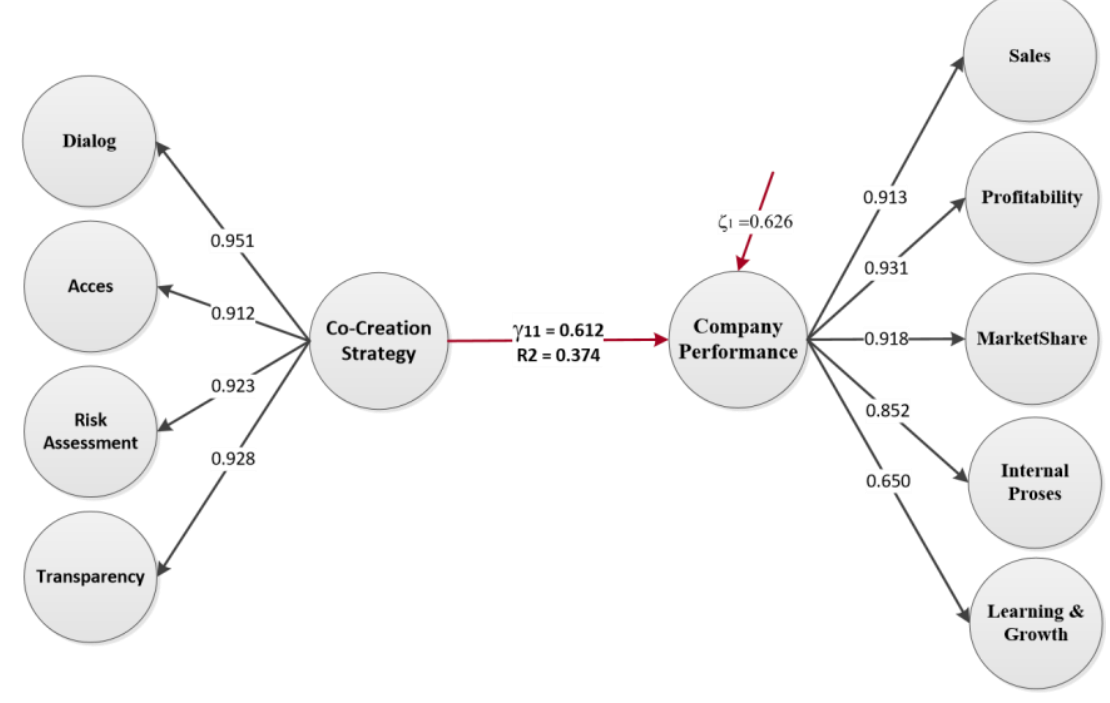

Figure 2. Finding Models

The findings indicate that the co-creation strategy has a direct positive and significant influence on company performance in Indonesia's wholesaler telecoms business. The results of testing the hypothesis support the research findings found by Hamidi and Gharneh, which states that Co-creation affect the performance of the company on Iranian's companies[3]; and Verma et al. on the study that provides insights into service co-creation and company success, as well as a substantial contribution to the marketing services literature addressing the influence of customer and business partner co-creation on company performance[8]. Additionally, the other study by Garcia Haro, Martnez Ruiz, and Martnez Caas indicated the existence of both direct and indirect 
impacts of the firm and customer co-creating activities[4].

\section{CONCLUSION}

The findings of this study demonstrate that the Co-creation Strategy can improve a company's performance. Co-creation occurs when a business collaborates closely with individuals or other businesses to develop new products, generate new ideas in the field of logistics, or to innovate, in which the ability of dialogue, interaction, and involvement of related parties, as well as sharing learning and communication to solve problems, becomes more accessible, and the disclosure of information (transparency) about the product, technology, and business systems becomes more accessible, to cr dialogue is more than simply listening to clients; it entails collaborative learning and conversation between two equal problem solvers. Dialogue fosters the formation and maintenance of local communities. Additionally, businesses can engage consumers as collaborators more effectively by combining the pillars of openness, risk assessment, access, and discussion. Transparency can make it easier to collaborate with consumers.

\section{REFERENCES}

[1] Adcock, A. \& Collier, D. (2001) Measurement validity: A shared standard for qualitative and quantitative research. American Political Science Review Ninetyfive (03), 529-546

[2] Arseculeratne, Dinuk dan Yazdanifard, R. (2014). How Green Marketing Can Create a Sustainable Competitive Advantage for a Business, International Business Research. 7: 130-137.

[3] Chinn, W. W. (1998). The Partial Least Squares Approach to Structural Equation Modelling. Modern Methods for Business Research, 29(2).

[4] Hair, J. F. Jr., Anderson, R. E., Tatham, R. L., and Black, W. C. (2006) Multivariate data analysis (5th ed.), Pearson Edition, New Del

[5] Hamidi, F., \& Gharneh, N. S. (2017). Impact of co-creation on innovation capability and firm performance: a structural equation modeling. AD-Minister, 30(4), 73-90. https://doi.org/10.17230/administer.30.4

[6] Haro, M. A. G., Martinez-Ruiz, M. P., \& Martinez-Canas, R. (2014). The Effects of the Value CoCreation Process on the Consumer and the Company. Expert Journal of Marketing, 2(2).

[7] Hilman, H. and Kaliappen, N. (2014) Market Orientation Practices and Effects on Organizational Performance: Empirical Insight from Malaysian Hotel Industry. SAGE Open, 4, 1-8. http://dx.doi.org/10.1177/2158244014553590

[8] Prahalad, C.K. \& Ramaswamy, V. (2004c). The Future of Competition: Co-Creating Unique Value with Customers. Harvard Business School Press. Boston, MA.

[9] Saarijarvi, H., \& Kannan, P.K. (2013). Value cocreation: theoretical approaches and practical implications. European Business Review, 1, 619.

[10] Teeratansirikool, L., Siengthai, S., Badir, Y., \& Charoenngam, C. (2013). Competitive strategies and firms performance: The mediating role of performance measurement. International Journal of Productivity and Performance Management, 62(2), 168 - 184.

[11] Vargo, S.L. \& Lusch, R.F. (2008). Servicedominant logic: continuing the evolution. Journal of the Academy of Marketing Science, $36,1-10$

[12] Verma et al. (2013) dalam Impact of service cocreation on the performance of firms: The mediating role of market-oriented strategies. International Journal of Services and Operations Management 15(4):449 